\title{
Implementation of Batchwise Bioscouring of Cotton Knits
}

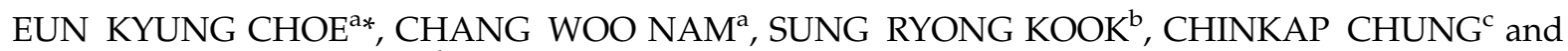 \\ ARTUR CAVACO-PAULO \\ ${ }^{a}$ Textile Ecology Laboratory, Korea Institute of Industrial Technology, 35-3, HongChonRi, IbJangMyun, 330-825 ChonAn, South Korea; ${ }^{b}$ WS DyeTech \\ Co., Ltd., Ansan, South Korea; ${ }^{c}$ Department of Chemistry, Keimyung University, Daegu, South Korea; ${ }^{d}$ Department of Textile Engineering, \\ University of Minho, Portugal
}

(Received for publication 28 June 2004; Revised manuscript accepted 3 November 2004)

The examination of critical factors determining the performance of bioscouring showed that a short treatment of the fabric at greater than $80^{\circ} \mathrm{C}$ after pectinase treatment at $60^{\circ} \mathrm{C}$ was essential for removal of waxes from the fabric as demonstrated by diminished intensities of methylene peaks in FT-IR measurements. Batchwise bioscouring of cotton knits was carried out several times with post-treatment at $80^{\circ} \mathrm{C}$ using a rapid dyeing machine. The dye-ability of bioscoured knits was as good as the company's alkaline scoured ones with slightly higher $K / S$ values. Water pollution caused by effluents of bioscouring and alkaline processes were estimated, as well as that due to the input of chemicals and enzymes. Higher BOD:COD $\mathrm{Cr}_{\mathrm{r}}$ ratios for enzymes indicated their biodegradable character. After calculation of energy consumption using a simulation program, an economic evaluation of the two processes was done on the basis of one ton production by considering the costs of chemicals and enzyme, water usage, energy consumption and waste water treatment charge.

Keywords: Bioscouring; After-treatment; Pectinase; Cotton knits; Water pollution; Energy consumption

\section{INTRODUCTION}

The conventional highly alkaline preparation of cotton is an example of a wet chemical process having a negative environmental impact. The alternative, an enzymatic process operating at a lower temperature, developed in the last five years using Novozyme's pectinase, is regarded as a cleaner production technology which reduces environmental impact by offering water and energy savings with additional benefits in improved quality ( $\mathrm{Li}$ and Hardin, 1997; Hartzell and Hsieh, 1998; Buchert and Pere, 2000; Durden et al., 2001; Etters et al.,
2001; Tzanov et al., 2001; Waddell, 2002). Despite frequent reports on the bioscouring of cotton, its industrial use has not spread rapidly worldwide. After a field trip to an industrialized bioscouring site, laboratory examination of critical process parameters (Kim et al., 2004) and satisfactory results on cotton knits in pilot and plant bioscouring trials, two textile dyeing companies adopted the new process in early 2004 to produce dark color cotton knits that comprise about $30 \%$ of their production. In this paper, we report the importance of a short high temperature post-treatment step, of enzyme-treated fabric and industrialized enzymatic scouring process for knitted cotton fabrics, as well as its environmental and economic evaluation.

\section{EXPERIMENTAL}

\section{Fabric Preparation for FT-IR Measurements}

An interlock knitted 100\% cotton greige fabric $\left(\mathrm{Ne}=40,160 \mathrm{~g} / \mathrm{m}^{2}\right)$ was bioscoured using $0.1 \%$ $(\mathrm{w} / \mathrm{v})$ of BioPrep L having an activity of 3000 ASPU $/ \mathrm{g}$, in the presence of $1 \mathrm{~g} / \mathrm{L}$ wetting agent (DGA W-15, mixture of nonionic and anion types, Dong-A Petrochemical) at $\mathrm{pH} 8.5$, adjusted with Tris- $\mathrm{HCl}$ buffer. After treatment for 20 minutes at $60^{\circ} \mathrm{C}$, fabrics were further processed with and without after-treatment at $95^{\circ} \mathrm{C}$ for 5 minutes. A laboratory IR dyeing machine (DL-6000 Starlet ${ }^{\circledR}-2$, Korea) was used for treatment, with a liquor ratio of 1:20. Treated samples were washed with distilled water, dried and conditioned for measurements.

\footnotetext{
* Corresponding author. Tel.: + 82-41-589-8594. Fax: + 82-41-589-8550. E-mail: ekchoe@kitech.re.kr
} 


\section{Pilot and Industrial-scale Bioscouring}

Knitted $100 \%$ cotton fabrics (interlock, $\mathrm{Ne}=40$, $160 \mathrm{~g} / \mathrm{m}^{2}$; single jersey, $\mathrm{Ne}=60,121 \mathrm{~g} / \mathrm{m}^{2}$ ) were bioscoured using a vertical winch dyeing machine of $20 \mathrm{~kg}$ capacity and a rapid dyeing machine of $100 \mathrm{~kg}$ capacity in WS Dyetech Co. according to process B in Fig. 1. A sequestering agent at $1 \mathrm{~g} / \mathrm{L}$, a scouring/ wetting agent at $1 \mathrm{~g} / \mathrm{L}$ and an anti-creasing agent at $1 \mathrm{~g} / \mathrm{L}$ (optional) were added to a bath with a liquor ratio of 1:8. Fabric was loaded and the $\mathrm{pH}$ adjusted to 8.5 by adding soda ash in a range of 0.25 to $0.5 \mathrm{~g} / \mathrm{L}$. When the temperature had been raised to $60^{\circ} \mathrm{C}, 0.5 \mathrm{~g} / \mathrm{L}$ Scourzyme $\mathrm{L}$ having an activity of $375 \mathrm{ASPU} / \mathrm{g}$ was added and the fabric was treated for 15 minutes at $60^{\circ} \mathrm{C}$, post-treated at $85^{\circ} \mathrm{C}$ for 15 minutes and washed at $60^{\circ} \mathrm{C}$ for 10 minutes. The corresponding alkaline scouring was carried out with the same fabrics and machines according to the process in Fig. 1 using the company's conventional recipe: sequestering agent at $1 \mathrm{~g} / \mathrm{L}$, scouring/ wetting agent at $1 \mathrm{~g} / \mathrm{L}$, anti-creasing agent at $1 \mathrm{~g} / \mathrm{L}$ (optional) and soda ash at $5 \mathrm{~g} / \mathrm{L}$ with a bath ratio of 1:8. The alkaline scoured fabric was washed twice at $80^{\circ} \mathrm{C}$ for 10 minutes and then at $50^{\circ} \mathrm{C}$ for 15 minutes with $0.5 \mathrm{~g} / \mathrm{L}$ formic acid in both washings.

\section{Pilot-scale Dyeing of Scoured Fabrics}

Parts of fabrics that had been bioscoured and alkaline-scoured were taken and sewn together to be dyed in the same bath using a vertical winch dyeing machine of $20 \mathrm{~kg}$ capacity. Cibacron Yellow F3R, Red

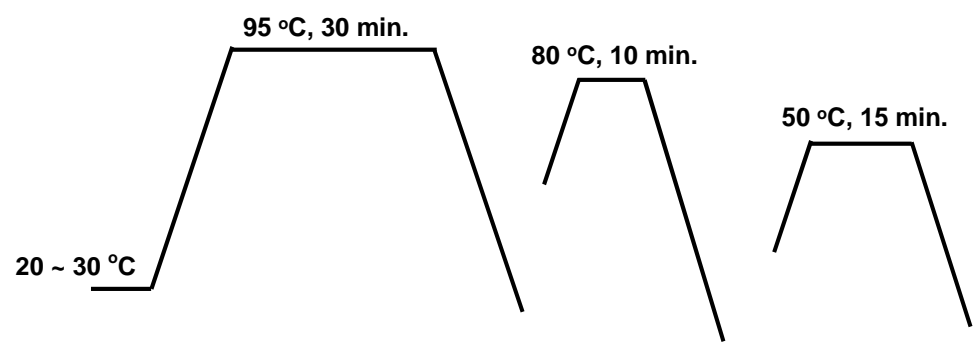

Alkaline Scouring

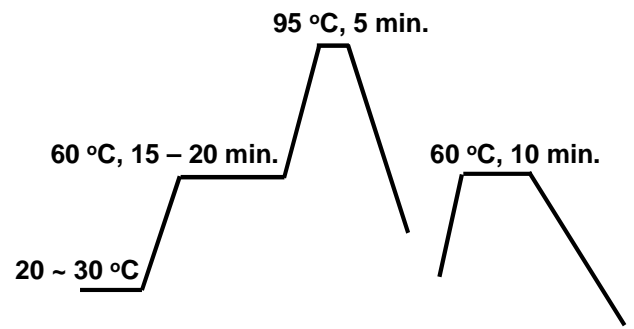

Bioscouring A

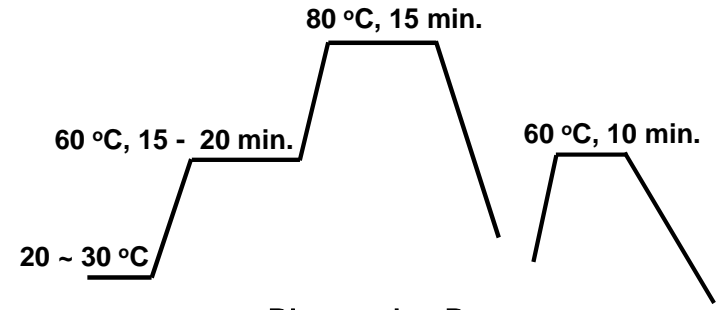

Bioscouring B

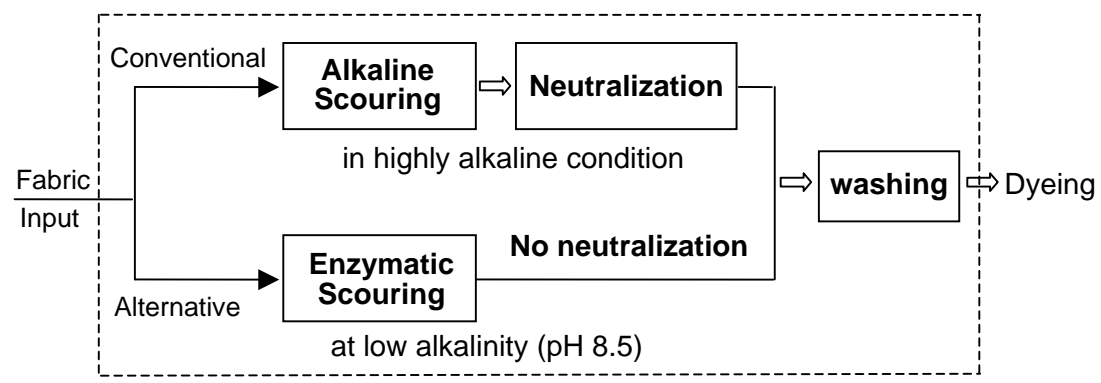

FIGURE 1 Process profiles for enzymatic versus alkaline scouring of cotton knits. 
FNR and Blue FNR were used according to the recommended recipe $(70 \mathrm{~g} / \mathrm{L}$ of Glauber salt, $20 \mathrm{~g} / \mathrm{L}$ of soda ash, with dyeing at $60^{\circ} \mathrm{C}$ followed by soaping at $98^{\circ} \mathrm{C}$ ).

\section{Surface Measurements of Fabrics by FT-IR}

Scouring results were monitored by FT-IR ATR spectroscopy. All the FT-IR spectra (256 scans, $4 \mathrm{~cm}^{-1}$ resolution) were measured with a ThermoNicolet Nexus FT-IR spectrophotometer. A single reflection horizontal ATR accessory by PIKE technology was used with a diamond ATR crystal. A $5 \mathrm{~mm} \times 5 \mathrm{~mm}$ piece of each fabric sample was mounted on top of the ATR crystal and pressed gently with the pre-mounted sample clamp. The ATR effect and atmospheric contributions from carbon dioxide and water vapor were corrected by the Omnic software.

\section{Fabric Testing}

Treated fabrics were conditioned and subjected to a water drop test. Color measurements of scoured fabrics and dyed fabrics were taken with Macbeth Color Eye 3000 using $D_{65}$ daylight as the illuminant. The fabrics were taken from each bath after scouring and washing, respectively and the $\mathrm{pH}$ of the processed fabric was measured according to $\mathrm{EN}$ 1413 (extraction in $\mathrm{KCl}$ solution and measurement of resulting solution by a $\mathrm{pH}$ meter).

\section{Water Pollution Measurements}

Textile chemicals and the enzymes used for pretreatment were obtained as commercial end products from textile companies. Wastewater was sampled from bioscouring and alkaline scouring done in a rapid dyeing machine. Water pollution parameters such as $\mathrm{BOD}_{5}, \mathrm{COD}_{\mathrm{cr}}, \mathrm{COD}_{\mathrm{Mn}}$, TOC, TDS, color density and $\mathrm{pH}$ were measured according to the well-established methods (Standard methods for the examination of water and wastewater, American Public Health Association, 1995). Chemicals and enzymes were diluted 1000 times $(\mathrm{v} / \mathrm{v})$ and subjected to TOC and COD measurements. Measured values in ppm were divided by the specific gravity of each liquid chemical to estimate how much each contributed to the water pollution load when one gram was dissolved in one liter of water. The resulting values were in $\mathrm{ppm} /(\mathrm{g} / \mathrm{L})$ which is also equivalent to $\mathrm{g} / \mathrm{kg}$, the units of COD or TOC in grams generated by one $\mathrm{kg}$ of auxiliaries (Choe et al., 2003).

\section{Calculation of Energy Consumption}

The energy consumption of the two processes was calculated using a simulation program (Cho, 2002) that estimates total energy demand, including consumption of steam and electricity for a chosen process. The program has an unique formula for calculating energy consumption according to the type of machine, using some constants such as specific heat of water, specific heat of fabric, average specific heat of steel, latent heat of water evaporation, energy per $1 \mathrm{~kg}$ of steam and energy per $1 \mathrm{kWh}$ of electricity, etc. A tube rapid dyeing machine was chosen with input parameters of $1000 \mathrm{~kg}$ weight, $11.2 \mathrm{~m}^{2}$ surface and electric power of $6.8 \mathrm{kWh}$. Energy consumption in calories needed to produce $100 \mathrm{~kg}$ fabric weight with a bath ratio of 1:8 using the rapid dyeing machine with temperature rate of $2{ }^{\circ} \mathrm{C} / \mathrm{min}$. was calculated (the alkaline souring and bioscouring B described in Fig. 1).

\section{Economic Evaluation}

The amounts of each chemical, enzyme, water and wastewater discharged were estimated according to the recipe described in the industrial-scale bioscouring and alkaline scouring. Costs were calculated in Korean won, and the totals converted into US dollars (USD). Costs for steam and electricity were obtained using 68 won (0.06 USD) per $\mathrm{kWh}$ and 14,000 (1.67 USD) won per ton. Economic evaluation of the two processes was done on the basis of scouring one ton of cotton knits with a bath ratio of 1:8.

\section{RESULTS AND DISCUSSION}

\section{Evaluation of Pectin and Wax Removal by FT-IR}

The purpose of the scouring process is to remove hydrophobic substances in the fiber to produce high wettability. The wax components, fatty acids, longchain alcohols and their ester compounds, are believed to be located in the primary cell wall with the highest concentration at the surface, and to be closely connected with the pectic substances (Waddell, 2002). We showed that FT-IR ATR spectroscopy which is a surface sensitive technique, could measure the presence of waxes and pectins, at least semi quantitatively (Chung et al., 2004). Figure 2 shows the FT-IR ATR spectra of processed and unprocessed fabrics. Figure 2(a) is the spectrum of the fabric processed by conventional alkaline scouring, which shows typical characteristic peaks for pure cellulose. The broad $\mathrm{C}-\mathrm{H}$ stretching band appears in the 2800 to $3200 \mathrm{~cm}^{-1}$ region. The spectrum of greige fabric in Fig. 2(d) shows extra peaks at 2918 and $2849 \mathrm{~cm}^{-1}$, which correspond to the asymmetric and the symmetric stretching modes 


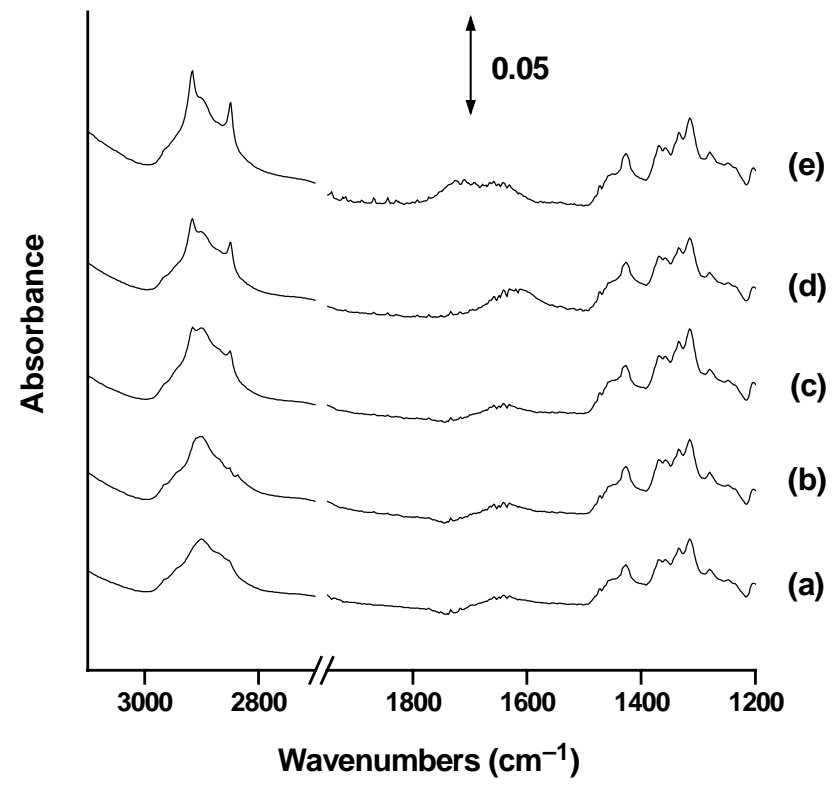

FIGURE 2 FT-IR ATR spectra of cotton fabrics: (a) alkaline scoured, (b) enzyme scoured at $60^{\circ} \mathrm{C}$ and after post-treatment at $95^{\circ} \mathrm{C}$, (c) enzyme scoured at $60^{\circ} \mathrm{C}$, (d) greige, (e) greige exposed to $\mathrm{HCl}$ vapor. The spectra (a), (d), and (e) are from Chung et al . (2004).

of methylene $\left(-\mathrm{CH}_{2}-\right)$ groups in long alkyl chains. The presence of these peaks indicates the presence of waxes. Normally waxes are mixtures of hydrocarbons and alkyl carboxylates, both of which have relatively large numbers of methylene groups in their structure. Figure 2(b) and 2(c) show the spectra of bioscoured fabrics. The intensities of methylene peaks at 2918 and $2849 \mathrm{~cm}^{-1}$ for bioscoured fabrics indicate the amount of wax remaining. When the fabric was treated with enzyme at $60^{\circ} \mathrm{C}$ for 15 minutes, the peak intensities at 2918 and $2849 \mathrm{~cm}^{-1}$ were reduced somewhat compared to the greige fabric. However, there were still traces of waxes left on the surface, as shown in Fig. 2(c). However, the fabric treated with enzyme at $60^{\circ} \mathrm{C}$ for 15 minutes, followed by washing at $95^{\circ} \mathrm{C}$ showed no trace of waxes (see Fig. 2(b)). Water drop tests gave results of less than one second for cotton knits that were alkaline scoured or bioscoured with post-treatment. This agreed with the FT-IR measurements.

Our previous results (Chung et al., 2004) showed that other information could be obtained in the region between 1600 and $1800 \mathrm{~cm}^{-1}$. At first glance, not much difference can be seen in the spectra for greige and scoured fabrics, as shown in spectra (a) to (d) in Fig. 2. However, when the fabrics were exposed to hydrochloric acid vapor for one minute, the presence of wax or pectins can be seen with the appearance of a peak at around $1750 \mathrm{~cm}^{-1}$. This peak is probably from the protonation of carboxylate ion groups in pectins and fatty acids of the waxes. In the spectrum (d) of the greige fabric, no peak at $1750 \mathrm{~cm}^{-1}$ was observed. After hydrochloric acid vapor exposure, the asymmetric carboxylate ion mode at $1600 \mathrm{~cm}^{-1}$ transformed to a carbonyl mode of carboxyl acid at $1750 \mathrm{~cm}^{-1}$ in spectrum (e). Alkaline scoured fabric did not show this transformation because the waxes and pectins responsible for this transformation were removed by scouring. Fabric that was bioscoured properly did not have waxes left, as seen in spectrum (b).

\section{Process Parameters for Bioscouring}

As discussed above, FT-IR measurement revealed that a short, high temperature post-treatment at, for example, $95^{\circ} \mathrm{C}$, should follow the pectinase treatment at $60^{\circ} \mathrm{C}$ for removal of the wax component from cotton. Laboratory examination of other factors for successful bioscouring showed that the right selection of surfactant functioning both in wetting, in the pectinase reaction and for emulsification in subsequent post-treatment procedures was essential, while the $\mathrm{pH}$ of the bath at $60^{\circ} \mathrm{C}(6.5$ or 8.5$)$ did not significantly influence the resulting absorbance of the fabric (Kim et al., 2004). The wetting agent that the company normally used for alkaline scouring was also used in the industrial bioscouring trials because, in laboratory experiments, it proved to be as good as DGA W-15, the standard surfactant for comparison. Processes A and B described in Fig. 1 are process profiles for bioscouring of cotton knitted fabric that have been industrialized in the United States and Turkey, respectively. Industrial-scale bioscouring was carried out with process B instead of process A due to energy saving, which will be discussed later.

\section{Color Strength of Dyed Fabrics}

Industrial scale bioscouring and alkaline scouring operations, using the same fabric and machine were done for comparison. Both scoured fabrics were dyed without bleaching. When the appearances of the scoured fabrics were compared, the bioscoured one tended to be more yellow with a darker grey, and slightly more yellow or almost the same with a paler grey. This was probably due to more aggressive and non-specific chemical attack of the alkali as compared to the enzyme. Table I shows typical examples of this tendency and the color strength of dyed fabrics. $L$ and $b$-values were used to describe the color of the undyed fabrics. According to a previous study (Park and Obendorf, 1994), a $\Delta b$ of 0.6 was reported to be comparable to visual observation of yellowness in undyed cotton fabric. In Table I, the $b$-values measured ( $b=6.8$ vs. 6.0$)$ agreed with the visual observation of a slightly more yellow 
TABLE I Color measurements of scoured and dyed fabrics

\begin{tabular}{|c|c|c|c|c|c|c|c|c|}
\hline \multirow[b]{2}{*}{ Fabrics } & \multicolumn{2}{|c|}{ Greige } & \multicolumn{2}{|c|}{ Bioscoured } & \multicolumn{2}{|c|}{$\begin{array}{l}\text { Alkaline } \\
\text { scoured }\end{array}$} & \multirow{2}{*}{$\begin{array}{c}\text { Bioscoured } \\
\text { and dyed } \\
\mathrm{K} / \mathrm{S}\end{array}$} & \multirow{2}{*}{$\begin{array}{c}\text { Alkaline scoured and } \\
\text { dyed } \\
\text { K/S }\end{array}$} \\
\hline & $\mathrm{L}$ & $\mathrm{b}$ & $\mathrm{L}$ & $\mathrm{b}$ & $\mathrm{L}$ & $\mathrm{b}$ & & \\
\hline Interlock knitted cotton $\mathrm{Ne}=40,160 \mathrm{~g} / \mathrm{m}^{2}$ & 81.2 & 16.1 & 83.4 & 14.0 & 83.8 & 12.2 & 9.73 Dark khaki & 8.87 Dark khaki \\
\hline Single jersey knitted cotton $\mathrm{Ne}=60,121 \mathrm{~g} / \mathrm{m}^{2}$ & 85.0 & 10.1 & 87.5 & 6.8 & 87.4 & 6.0 & 0.48 Pale grey & 0.47 Pale grey \\
\hline
\end{tabular}

fabric. Dyeing of scoured fabric of each set showed good dyeability. Whether a deeper color of the bioscoured fabric resulted from the more yellow color of the bioscoured fabric needs to be further studied. Another possible reason for this result is the higher alkaline residue of alkaline scoured fabric, causing hydrolysis of reactive dyes.

\section{Water Use Before and After Scouring}

Traditional scouring of cotton fabrics leaves high levels of alkali in the fabric (Table II), that must be neutralized before proceeding to dyeing. After alkaline scouring, two cycles of washing are needed with acetic or formic acid added to the first or second wash water. In our operation, formic acid was added in the second wash water. Table II shows that the $\mathrm{pH}$ of the bath decreased significantly back to $\mathrm{pH} 7$ only after neutralization. It was observed that the final $\mathrm{pH}$ of the bioscouring bath was lower than the initial $\mathrm{pH}$ value of 8.5 when the $\mathrm{pH}$ was adjusted by using sodium carbonate instead of a buffer system. The substitution of mildly alkaline enzymatic scouring for highly alkaline conventional scouring eliminated the use of caustic soda completely or decreased the amount of soda ash dramatically, as shown in Table III. A neutralization process is not needed with enzymatic scouring. Approximately 8 tons of washing water and $4 \mathrm{~kg}$ of acetic or formic acid are saved per one ton fabric production (Table III \& IV) with a bath ratio of 1:8. Wastewater is also decreased by as much as the amount of water saved in the production process.

\section{Water Pollution Load of Effluent}

The organic pollution for conventional alkaline scouring, including TOC, COD using $\mathrm{KMnO}_{4}$ and $\mathrm{K}_{2} \mathrm{Cr}_{2} \mathrm{O}_{7}$ and $\mathrm{BOD}$, was approximately one and half to two times higher than for bioscouring as shown in Fig. 3. Color density and the total dissolved solids of alkaline scouring were two and eight times higher, respectively. The higher organic pollution and color density of alkaline scouring effluent resulted from greater removal of non-cellulosic materials from cotton fabric as can be seen in the fabric appearance (Table I). Larger amounts of total dissolved solids are usually generated in the neutralization step after alkaline scouring, due to the use of acids.

\section{Water Pollution Load Due to Chemical and Enzyme Inputs}

The water pollution load generated from each chemical and enzyme for one ton production of fabric is presented as $\mathrm{COD}_{\mathrm{Cr}}$ in Table III. To compare the pollution load of each chemical, $\mathrm{COD}_{\mathrm{Cr}}$ per unit amount of chemical was multiplied by its dosage. The same amount of wetting agent, anti-creasing agent and sequestering agent was used in both processes. The increase in $\mathrm{COD}_{\mathrm{Cr}}$ due to enzymes was very small, since its dosage was about one eighth to one tenth of other auxiliaries, depending on the bath ratio. Acetic acid added in the washing step after alkaline scouring was estimated to create a large amount of the $\mathrm{COD}_{\mathrm{Cr}}$. The dosage of each chemical in Table III was also used for calculation of costs due to chemicals and enzymes.

Parameter BOD:COD ${ }_{\text {cr }}$ ratios were calculated for each agent and are plotted in Fig. 4. The ratios are less than one because values for $\mathrm{COD}_{\mathrm{cr}}$ are always higher than those for BOD (Corbitt, 1990). The BOD/ COD ratios for enzymes vary from 0.61 to 0.74 while those for chemicals are less than 0.37. Higher $\mathrm{BOD}: \mathrm{COD}_{\mathrm{cr}}$ ratios for enzymes indicate their biodegradable character.

\section{Energy Consumption}

Energy use was calculated for each step. These included scouring, after-treatment and washing for bioscouring and alkaline scouring, and first and

TABLE II Comparison of $\mathrm{pH}$ values of fabrics and processing water taken from each step of bioscouring and alkaline scouring

\begin{tabular}{|c|c|c|c|c|c|}
\hline & \multicolumn{2}{|c|}{ Bioscouring } & \multicolumn{3}{|c|}{ Alkaline scouring } \\
\hline & Scouring bath & Washing bath & Scouring bath & $1^{\text {st }}$ Washing bath & $2^{\text {nd }}$ Washing bath \\
\hline Processing water & 7.1 & 6.7 & 11.1 & 10.4 & 7.6 \\
\hline Fabric & 6.8 & 6.0 & 9.2 & 8.5 & 7.6 \\
\hline
\end{tabular}


TABLE III Estimation of CODcr due to input of each chemical for one ton production of cotton knits

\begin{tabular}{|c|c|c|c|c|c|c|}
\hline \multirow[b]{2}{*}{ Raw materials } & \multicolumn{3}{|c|}{ Bioscouring } & \multicolumn{3}{|c|}{ Alkaline scouring } \\
\hline & Amount used (kg) & $\operatorname{CODcr}(\mathrm{g} / \mathrm{kg})^{*}$ & CODcr $(\mathrm{g})$ & Amount used (kg) & $\operatorname{CODcr}(\mathrm{g} / \mathrm{kg})^{*}$ & CODcr $(\mathrm{g})$ \\
\hline BioPrep & 1 & 267 & 267 & - & - & - \\
\hline Soda ash & 2.5 & - & - & 40 & - & - \\
\hline Wetting/Scouring agent & 8 & 424 & 3392 & 8 & 424 & 3392 \\
\hline Anti-creasing agent & 8 & 295 & 2360 & 8 & 295 & 2360 \\
\hline Sequestring agent & 8 & 184 & 1472 & 8 & 184 & 1472 \\
\hline Acetic acid & - & - & - & 4 & 966 & 3864 \\
\hline Total & & & 7,491 & & & 11,088 \\
\hline
\end{tabular}

${ }^{*}$ Amount of $\mathrm{COD}$ in g generated by one $\mathrm{kg}$ of chemical or enzyme of commercially available state.

TABLE IV Description of the overall financial picture based on one ton production of cotton knits

\begin{tabular}{|c|c|c|}
\hline & Enzymatic scouring & Alkaline scouring \\
\hline \multicolumn{3}{|l|}{ Costs: 11.9 USD UP } \\
\hline Investment & Not needed (the same facility is used) & \\
\hline Raw materials & Chemicals including Enzyme: 58.6 USD & Chemicals including Alkali: 46.7 USD \\
\hline \multicolumn{3}{|l|}{ Savings: 16.5 USD Down } \\
\hline Water & 16 tons $=5.3 \mathrm{USD}$ & 24 tons $=8.0 \mathrm{USD}$ \\
\hline Wastewater treatment & 16 tons $=10.7$ USD & 24 tons $=16.0$ USD \\
\hline $\begin{array}{l}\text { Operation: reduction of energy } \\
\text { use such as steam and electricity }\end{array}$ & 32.7 USD & 41.2 USD \\
\hline Overall & \multicolumn{2}{|c|}{$\begin{array}{l}\text { Increase due to enzyme cost (11.9 USD) is offset by savings (16.5 USD) from water, wastewater } \\
\text { treatment and steam and electricity. }\end{array}$} \\
\hline
\end{tabular}

second washing for alkaline scouring. For example, to calculate the energy consumed for the bioscouring post-treatment step (step 2 in Fig. 5), the initial and final temperatures of $60^{\circ} \mathrm{C}$ and $95^{\circ} \mathrm{C}$ and the duration time of 5 minutes at $95^{\circ} \mathrm{C}$ were input while the corresponding $25^{\circ} \mathrm{C}, 95^{\circ} \mathrm{C}$ and 30 minutes at $95^{\circ} \mathrm{C}$ conditions were used for the alkaline scouring step (step 7 in Fig. 5). The calculated energy shows that energy consumption was more dependent on treatment temperature rather than treatment time. The
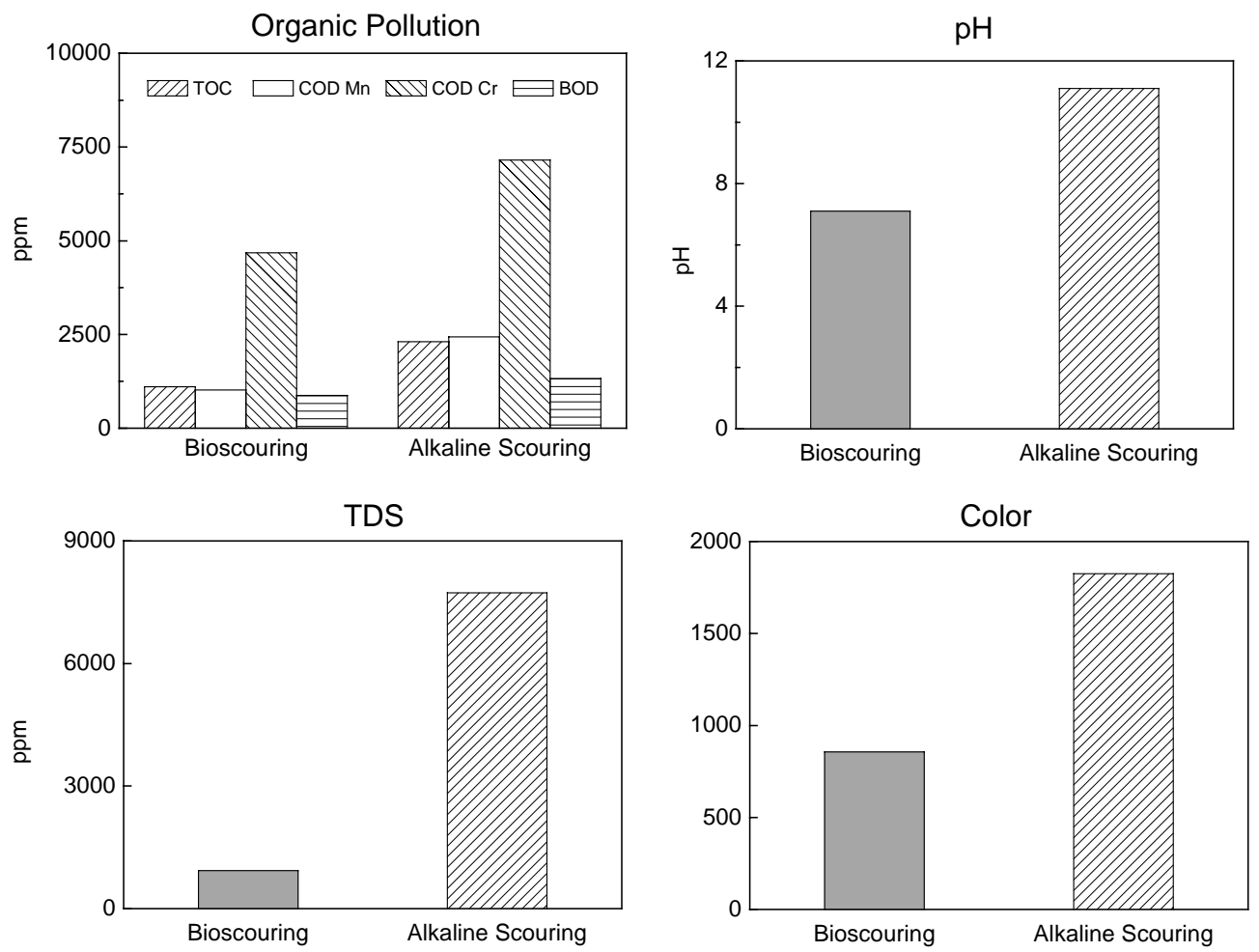

FIGURE 3 Water pollution load of effluents from bioscouring and alkaline scouring baths. 


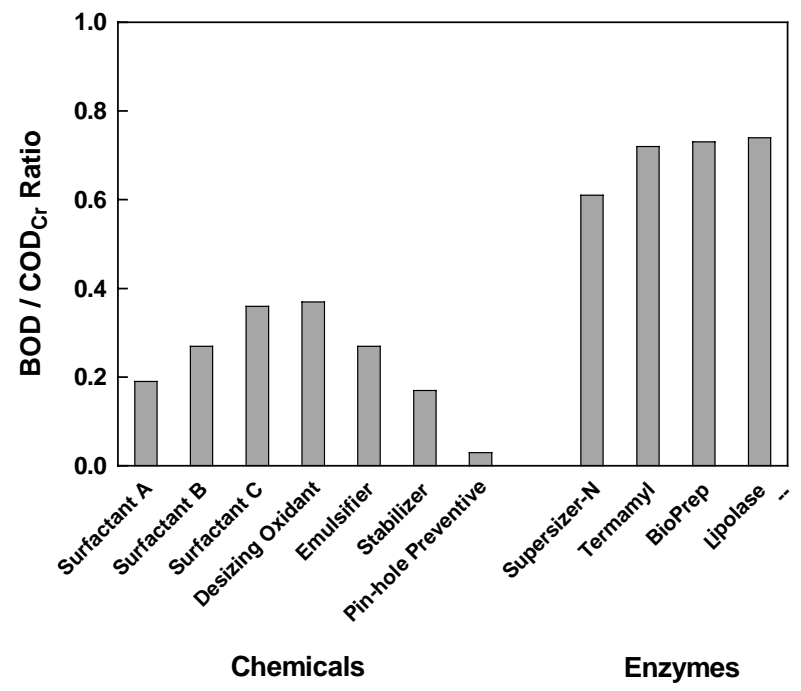

FIGURE 4 BOD to CODcr ratios of chemicals and enzymes, indicating the better biodegradability of enzymes. energy of each step was summed to give the total energy of bioscouring and alkaline scouring, as shown in Fig. 5.

\section{SUMMARY}

FT-IR ATR spectroscopy was introduced as a tool for monitoring scouring effects, suggesting the importance of a short treatment at high temperature after pectinase treatment at $60^{\circ} \mathrm{C}$. Batchwise bioscouring was carried out for knitted cotton fabrics on pilot and industrial scales. The dyeability of bioscoured knits was as good as the company's alkaline scoured ones.

A scheme for estimating the environmental load, as well as the energy, chemical and water consumption was constructed. This gave an economic evaluation of the batchwise bioscouring for knitted cotton fabric, which showed that bioscouring is an economically feasible process based on our local costs of
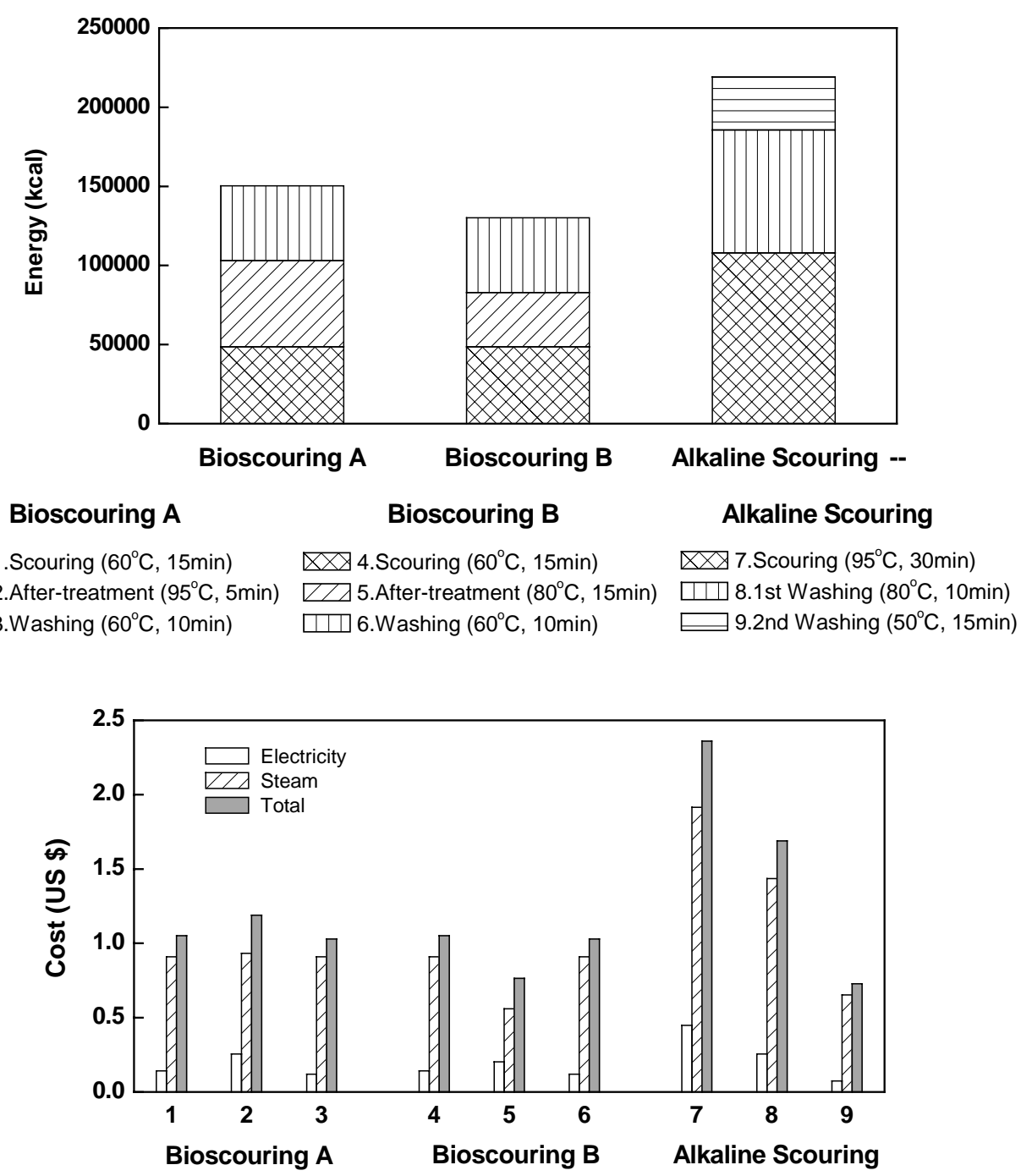

FIGURE 5 Comparison of energy costs for bioscouring and alkaline scouring per $100 \mathrm{~kg}$ production of cotton knits as calculated by a simulation program. 
water, wastewater treatment, steam, electricity, chemical and enzymes. This is summarized in Table IV.

Feedback from the company is that a major benefit of bioscouring is softness to the touch of its final products. The softness of the final fabric could allow a reduction in the amount of softening agent applied in the finishing step. Because the fabric was also soft in the treatment bath, the amount of anti-creasing agent could probably also be decreased. The disadvantage of bioscouring is that it is only easily applicable to dark colored products.

\section{Acknowledgements}

This work was done as a KNCPC (Korea National Cleaner Production Center)-funded technology transfer project. The authors wish to express their appreciation to Dr. L.T. Holst at Dexter Chemical L.L.C, Ms. S. Erkul at Taner Trico dyeing company in Turkey and Mr. H. Koo at WS DyeTech Co., Ltd. for their helpful discussions on bioscouring implementation. Mr. B.Y. Kim, J. Liu and M. Uygur at Novozymes kindly provided us with enzymes and technical discussions. The skilful technical assistance of S.H. Son and S.Y. Kim in our laboratory is gratefully acknowledged.

\section{References}

American Public Health Association (1995) Part 5210, Part 5220, Part 5310. In Standard methods for the examination of water and wastewater. 19th Ed. Washington, DC.
Buchert, J. and Pere, J. (2000) Scouring of cotton with pectinases, proteases, and lipases, Textile Chemist and Colorist $\mathcal{E}$ American Dyestuff Reporter 32, 48-52.

Cho, H.T. (2002) Program manual for calculation of energy consumption (Soongsil University Press Center, Seoul).

Choe, E.K., Son, S.H., Nam, C.W. and Park, Y.H. (2003) Method development for evaluating water pollution from textile processing, Proceedings of $7^{\text {th }}$ Asian Textile Conference S- 81 .

Chung, C., Lee, M. and Choe, E.K. (2004) Characterization of cotton fabric scouring by FT-IR ATR spectroscopy, Carbohydrate Polymers. 58, 417- 420.

Corbitt, R.A. (1990) Wastewater disposal, In: Corbitt, R.A., ed, Standard Handbook of Environmental Engineering (McGrawHill, Inc., New York), pp. 61- 274.

Durden, D.K., Etters, J.N., Sarkar, A.K., Henderson, L.A. and Hill, J.E. (2001) Advances in commercial biopreparation of cotton with alkaline pectinase, AATCC Review August, 28 31.

Etters, J.N., Sarkar, A.K., Henderson, L.A. and Liu, J. (2001) The influence of biopreparation of cotton with alkaline pectinase on dyeing properties, AATCC Review May, 2224.

Hartzell, M.M. and Hsieh, Y.-L. (1998) Enzymatic scouring to improve cotton fabric wettability, Textile Research Journal 68, $233-241$.

Kim, J., Choe, E.K., Kim, S.Y. and Nam, S.W. (2004), Important factors for successful enzymatic scouring, Abstracts of $3^{\text {rd }}$ International Conference on Textile Biotechnology P-22.

Li, Y. and Hardin, I.R. (1997) Enzymatic scouring of cotton: effects on structure and properties, Textile Chemist and Colorist 29, $71-76$.

Park, E.K.C. and Obendorf, S.K. (1994) Chemical changes in unsaturated oils upon aging and subsequent effects on fabric yellowing and soil removal, J. Am. Oil Chem. Soc. 71, $17-30$.

Tzanov, T., Calafell, M., Guebitz, G.M. and Cavaco-Paulo, A. (2001) Bio-preparation of cotton fabrics, Enzyme and Microbial Technology 29, 357-362.

Waddell, R.B. (2002) Bioscouring of cotton: commercial applications of alkaline stable pectinase, AATCC Review April, 28. 